\title{
Preliminary Phytochemical Screening and Toxicity Test of Leaf and Root Parts of the Snake Plant (Sansevieria trifasciata)
}

Julie S. Berame*, Sheena Mae E. Cuenca, Diana Rose P. Cabilin and Marycris L. Manaban

Department of Biology, College of Education, Caraga State University, Ampayon, Butuan City, 8600 Philippines

*Corresponding Author: Julie S. Berame, Department of Biology, College of Education, Caraga State University, Ampayon, Butuan City, 8600 Philippines, Tel: +63 9293950188; E-mail: janveel@yahoo.com

Receiving date: Sep 26, 2017; Acceptance date: Oct 13, 2017; Publication date: Oct 18, 2017

Copyright: ( 2017 Berame JS, et al. This is an open-access article distributed under the terms of the Creative Commons Attribution License, which permits unrestricted use, distribution, and reproduction in any medium, provided the original author and source are credited.

\begin{abstract}
Objective: To examine the toxicity level of Sansevieria trifasciata (Asparagaceae) leaves and roots extracts.

Methods: The antimicrobial activity was tested against alkaloid, saponins, tannins, anthraquinones screening by two different methods, the brine shrimp toxicity test and ten-fold serial dilution of the powdered plant material in artificial seawater.
\end{abstract}

Results: The results showed the presence of cytotoxic principles making it effective therapeutic remedy for treating various infections as it possesses effective of its zone of inhibition (lowest concentration of $35.22 \mu \mathrm{g} / \mathrm{ml}$ to the highest concentration of $44.49 \mu \mathrm{g} / \mathrm{ml}$ ) using brine shrimp bioassy of Sansevieria trifasciata roots and leaves extracts.

Conclusion: Thus, the toxic potential of the plant extracts yields greater than the recommended LC50 value and reveals positive linear relationship between the concentrations of the extract to the mortality rate using nauplii. The more concentrated the treatment the higher mortality had resulted.

Keywords: Phytochemical screening; Brine shrimp; Lethality test; Secondary metabolites; Snake plant

\section{Introduction}

Snake Plant is one of the most recommended plants for improving air quality. The optimal place to keep this is in your bedroom, because it converts $\mathrm{CO}_{2}$ into oxygen at night it also removes contaminants from air. The NASA conducts a study to the uses of snake plant according to their results they found out that the snake plant absorbs toxins, such as nitrogen oxides and formaldahyde. Sansevieria trifasciata is able to absorb 107 types of toxins, including air pollution, cigarette smoke (nicotine), so it would make a great refresher. It also contains phytochemicals such as flavonoids, saponins, and glycosides which reduce the number of bacteria [1]. In China, decoction used for detoxification, as anti-inflammatory, and for treatment of sores and snake bites. It also used to cure boils, cough, bronchitis, traumatic injuries [2].

The search for bioactive compounds for pharmaceutical and industrial applications is still being actively done. Philippine plant species that have been used for indigenous medicinal purpose serves as a reservoir of these compounds. At present, herbal medicines and food supplements are undeniably rampant as an alternative to synthetic drugs. Media advertisements as well as beauty cosmetics brochures and catalogues are flooded with varieties of botanicals and herbals. This is caused by widely accepted through that these products have no side effects, can easily absorbed by the body and can cure almost all of the common ailments; that is in comparison to synthetic drugs [3]. However, labels and packages of these sold herbal medicines states that it has no approved therapeutic claim.
This research would help in the discovery of a new form of medication for the upcoming severe diseases of microbial infection such as the leaves and roots of Sansevieria trifasciata are used in traditional medicine for the treatment of asthma, abdominal pains, colic, diarrhea, haemorrhoids, hypertension, menorrhagia, piles, sexual weakness, wounds of the foot, cough, leprosy, rheumatism, glandular enlargement, nutritional deficiencies and treatment of snake bite [4]. The active ingredient from the root is more natural, fewer chemicals so it consists less toxicity, side effects and safe compared to synthetic drugs [5]. The new discovery of this product will create awareness and revolute advantage of the Sansevieria trifasciata root usage [6,7]. This medication well tolerated by patients, with fewer unintended consequences than pharmaceutical drugs because it less toxic and side effects [8]. Thus, this study will be an important way of labelling the snake plant abundantly found in as ornamental plant in Caraga State University. Its bioactive ingredients were identified and its toxicity level for the effective future formulation of the plant as medicinal plant.

\section{Materials and Methods}

\section{Plant materials}

The Fresh leaves and roots of Snake plant were collected from the Engineering Department of Caraga State University along its side pavement and across the Horrizon Bridge on its paved aisle along the its pavement.

The leaves of Sansevieria liberica were collected in July 2017 from a single population of the plant from front of the Engineering Department of Caraga State University, Ampayon, Butuan City. The collected plant was authenticated with the biology department. 


\section{Preparation extract}

The collected plant parts were separated as leaf and roots and were cleaned with deionized water and dried under shade for two weeks at room temperature. Dried leaves and stem were grounded and filtered using $0.3 \mathrm{~mm}$ mesh. The plant powder was stored in air tight container and maintained at $4^{\circ} \mathrm{C}$ until use separately.

\section{Qualitative phytochemical screening}

Phytochemical analysis of each extract has been carried out according to standard protocols [9].

\section{Screening for alkaloid}

A $0.5 \mathrm{~g}$ of the extract was stirred in $5 \mathrm{ml}$ of $1 \% \mathrm{HCl}$ on a steam bath and filtered while hot. Distilled water was added to the residue and 1 $\mathrm{ml}$ of the filtrate was treated with a few drops of Wagner's reagent. A reddish brown precipitate indicates the presence of alkaloids. Screening for Flavonoids $2 \mathrm{ml}$ of dilute sodium hydroxide was added to $2 \mathrm{ml}$ of the extract. The appearance of a yellow colour indicates the presence of flavonoids.

\section{Screening for saponins}

A $1 \mathrm{ml}$ of distilled water was added to $1 \mathrm{ml}$ of the extract and shaken vigorously. A stable persistent froth indicated the presence of saponins. Screening for Phenols Equal volumes $(1 \mathrm{ml})$ of extract and Iron (III) chloride were mixed. A deep bluish green solution gave an indication of the presence of phenols.

\section{Screening for tannins}

A portion of the extract was dissolved in water, after which the solution was clarified by filtration. $10 \%$ ferric chloride solution was then added to the resulting filtrate. The appearance of a bluish black colour indicates the presence of tannins.

\section{Screening for anthraquinones}

A $0.5 \mathrm{~g}$ of the extract was shaken with $10 \mathrm{ml}$ of benzene and filtered. $10 \%$ of ammonia solution was added to filtrate and the mixture was shaken. The formation of a pink, red or violet colour on the ammoniacal phase [10].

\section{Brine shrimp bioassay}

The brine shrimp assay is a rapid, reliable and inexpensive general bioassay toxicity test for active plant extracts. The procedure allows the determination of the LC50 values in parts per million (ppm) of active constituents in the brine medium. This bioassay has been used in the analysis of natural products, pesticides residues and other chemical pollutants in marine environment [11].

\section{Hatching of brine shrimp}

Brine Shrimp egg, (Artemia salina) obtained from the local pet shop was hatched in a shallow rectangular plastic dish filled with 1 liter of artificial sea water, which was prepared with 35 grams commercial rock salt mixture and $1 \mathrm{~mL}$ distilled water. Approximately 1 gram of eggs was sprinkled in the compartment. An aquarium aerator was used for Artemia cyst suspension to provide an ample supply of oxygen in the medium. A perforated plastic cover was then put over the dish to avoid predatory insects on cysts or nauplii. The container was also well lighted with lamp to maintain the water temperature. After 3 days the hatched cysts have produced fast swimming nauplii which were used in this bioassay. A dropper and a micropipette were used to collect nauplii from the suspension.

\section{Ten-fold serial dilution of the powdered plant material in artificial seawater}

Three test tubes containing $0.1 \mathrm{~g}$ or $100 \mathrm{mg}$ of each powdered snake leaves and roots, $10 \mathrm{~mL}$ of artificial water was introduced and the test tube was corked and manually shaken by inverting 5 times. The concentration of the snake plant extract in this tube is $10 \mathrm{mg} / \mathrm{ml}$ or $10,000 \mathrm{u} g / \mathrm{mL}$. Using a permanent marker, this tube was labeled \# 1 . Five other tubes were labeled $2,3,4,5 \& 6$. The test tubes were placed in a rack side by side according to their number. To tubes \# 2,3,4,5 artificial seawater of $9 \mathrm{~mL}$ volume was added using $10 \mathrm{~mL}$ glass pipette and tube \# 6 was $10 \mathrm{~mL}$ artificial seawater and serves as control set-up.

\begin{tabular}{|l|l|l|l|l|l|}
\hline Tube \# & \# 1 & \# 2 & \# 3 & \# 4 & \# 5 \\
\hline Volume of ASW (Diluent) & $10 \mathrm{~mL}$ & $9 \mathrm{~mL}$ & $9 \mathrm{~mL}$ & $9 \mathrm{~mL}$ & $9 \mathrm{~mL}$ \\
\hline Volume of Original Plant Extract $(10 \mathrm{mg} / \mathrm{mL}$ ) Serially Diluted & - & $1.0 \mathrm{~mL}$ & $1.0 \mathrm{~mL}$ & $1.0 \mathrm{~mL}$ & $1.0 \mathrm{~mL}$ \\
\hline Total volume in tubes \# 1 to \# & $10 \mathrm{~mL}$ & $10 \mathrm{~mL}$ & $10 \mathrm{~mL}$ & $10 \mathrm{~mL}$ & $10 \mathrm{~mL}$ \\
\hline Dilution Series & 10 -fold & 10 -fold & 10 -fold & 10 -fold & 10 -fold \\
\hline Dilution Level of Originated Extract & 1 & $1: 10$ & $1: 100$ & $1: 1,000$ & $1: 10,000$ \\
\hline Concentration of Plant extract in $\mathrm{mg} / \mathrm{mL}$ from tubes \# 1 to \# 5 & 10 & 1.0 & 0.1 & 0.01 & 0.001 \\
\hline Concentration of plant extract in ứg/mL or ppm from tube \# 1 to \# 5 & 10,000 & 1,000 & 100 & 10 & 1 \\
\hline
\end{tabular}

Table 1: Ten-fold dilution series of the Three dried powdered specie of Sansevieria trifasciata in ASW of various concentrations ranging from 10, 000 ưg/mL to 1 úg/mL. Note: \# denotes Number.

The plant powder in tube \# $1(10 \mathrm{mg} / \mathrm{mL})$ was allowed to settle down for 1 hour. This should be produced a residue at the bottom and a clear supernatant liquid above it. After the plant powdered has settle to the bottom of tube \# $1,1 \mathrm{~mL}$ of the supernatant was gently withdrawn using a $1 \mathrm{~mL}$ micropipettor and transferred to tube \#2. Tube \#2 was corked and inverted 3 times to mix the content. Tube \# 2 was uncorked 
and return to its slot in the rack between \# 1 and \# 3 . Using again the micropipettor, $1 \mathrm{~mL}$ was removed from tube \#2 and transferred to tube \# 3 to tube \# 5 . This process performed is a 10 -fold serial dilution indicating that in each tube as one move from tube \# 1 to $\# 5$, the concentration of the plant extract is being reduced by 10 times of the tube previous to it shows in Table 1 .

\section{Bioassay}

In each snake plant extract, 18 vials contained with $5 \mathrm{~mL}$ ASW were prepared for the application. Approximately 10 shrimps were collected using a wide-mouth plastic medicine dropper. The shrimps were added to each vial. A magnifying lens was used for checking the viability and well-being of the nauplii. The plastic container was closed with a plastic cellophane cover and kept under white light during the 24 hours period. The numbers of viable nauplii (number of surviving) were counted in each vial after 24 hours. A pipette sucked into the vials was used to count the surviving shrimps macroscopically, held against a well-lighted background.

\section{Statistical analysis to determine the extracts LC50}

To determine the regression of equation for the data, the Coefficient $\mathrm{b}$ in the equation of a line $\mathrm{y}=\mathrm{a}+\mathrm{bx}$ is computed as

$$
b=\frac{n \sum x y-\sum x \sum y}{n \sum x^{2}-\sum(x)^{2}}
$$

The Coefficient from the equation of a line above is solved as $a=y-b x$ Where $y$ is the mean of $y$ (percent mortality) and $x$ is the mean of $x$ (log dose).

Assuming that $y=50 \%$ and substituting it to the regression equation above and then $\mathrm{x}$ was solved. And with a scientific calculator, antilog values achieved were converted it back to its dose in ppm to determine the LC50 of each snake plant extract in ppm. The resulting values were the concentration of the snake plant species that will kill $50 \%$ of the Artemia salina nauplii at 24 hours. Then correlation coefficient of the results on the data obtained was solved using the equation

$$
r=\frac{n \sum x y-\sum x \sum y}{\sqrt{\left(n \sum x^{2}-\sum(x)^{2}\right)-\left(n \sum y^{2}-\sum(y)^{2}\right)}}
$$

Furthermore, the toxicity rating of sample as also analysed according to the (\%) mortality group of the test organism which is show in Table 2 [12].

\begin{tabular}{|l|l|}
\hline Mortality & Toxicity \\
\hline $80-90$ & Highly toxic \\
\hline $50-79$ & Moderately toxic \\
\hline $30-49$ & Slightly toxic \\
\hline $0-29$ & Non-toxic \\
\hline
\end{tabular}

Table 2: The toxicity rating of extract based on percent (\%) mortality

Weigh 0.1 gram of the sample then dry it in oven at $50^{\circ} \mathrm{C}$ for about 4 to 6 hours until constant weight is obtained. Powderized the sample for the application in the tenfold dilution and for brine shrimp bio assay using the nauplii larvae.

\section{Bioassay procedure}

The procedure described in the literature [13] (Meyer et al. and McLaghin et al.) was adopted for this study. Samples of five different concentrations $1,10,100,1000,10000 \mu \mathrm{g} / \mathrm{ml}$ were prepared according to the direction given in the literature. Brine shrimp (Artemia salina Leach) nauplii were hatched in a specific plastic tank (Figure 1). Fifteen shrimps were transferred to each sample vial and then sea water was added to make the volume of $2 \mathrm{ml}$. The vials were kept for 24 hours, thereafter the active nauplii were counted with the aid of $3 x$ magnifying glass and the percent death at each dose and control was determined. The data obtained were processed in Probit Statistical Analysis by means of regression to estimate LC50 values for the significance of death, survival and the mortality of nauplii larvae.

\section{Results}

\section{Phytochemical screening of ethanolic extract}

The Table 3 and Table 4 below showed the result of the presence of the bioactive compounds found in both the leaves and root parts of the snake plant. It can be seen that both the leaves and roots were highly active with alkaloids, tannins and anthraquinones and two bioactive compounds were absent in the leaves and roots of plants were flavonoids and saponins.

\section{Ten-fold serial dilution of the powdered plant material in artificial seawater}

Three test tubes containing $0.1 \mathrm{~g}$ or $100 \mathrm{mg}$ of each powdered snake leaves and roots, $10 \mathrm{~mL}$ of artificial water was introduced and the test tube was corked and manually shaken by inverting 5 times. The concentration of the snake plant extract in this tube is $10 \mathrm{mg} / \mathrm{ml}$ or 10,000 ưg/mL. Using a permanent marker, this tube was labeled \# 1 . Five other tubes were labelled $2,3,4,5 \& 6$. The test tubes were placed in a rack side by side according to their number. To tubes \# 2,3,4,5 artificial seawater of $9 \mathrm{~mL}$ volume was added using $10 \mathrm{~mL}$ glass pipette and tube \# 6 was $10 \mathrm{~mL}$ artificial seawater and serves as control set-up. 
Citation: Berame JS, Cuenca SME, Cabilin DRP, Manaban ML (2017) Preliminary Phytochemical Screening and Toxicity Test of Leaf and Root Parts of the Snake Plant (Sansevieria trifasciata). J Phylogenetics Evol Biol 5: 187. doi:10.4172/2329-9002.1000187

Page 4 of 7

\begin{tabular}{|c|c|c|c|c|c|c|c|}
\hline \multirow[b]{2}{*}{ Plant Sample } & \multicolumn{2}{|l|}{ Test for Alkaloids } & \multicolumn{2}{|c|}{ Test for Tannins } & $\begin{array}{l}\text { Test for } \\
\text { Flavonoids }\end{array}$ & Test for Antraquinones & \multirow{2}{*}{\begin{tabular}{|l|}
$\begin{array}{l}\text { Test } \\
\text { Saponins }\end{array}$ \\
Froth Test
\end{tabular}} \\
\hline & Mayers Reagent & $\begin{array}{l}\text { Dragen- } \\
\text { dorffs } \\
\text { Reagent }\end{array}$ & Gelatin Test & $\begin{array}{l}\text { Ferric Chloride } \\
\text { Test }\end{array}$ & $\begin{array}{l}\text { Smith \& Metcalf } \\
\text { Method }\end{array}$ & $\begin{array}{l}\text { Borntrager's Test and } \\
\text { Modefied Borntrager's Test }\end{array}$ & \\
\hline $\begin{array}{l}\text { Snake Plant Leaves } \\
\text { Extract }\end{array}$ & ++ & ++ & ++ & $\begin{array}{l}\text { Brownish brown } \\
+\end{array}$ & - & + & - \\
\hline $\begin{array}{l}\text { Snake Plant Roots } \\
\text { Extract }\end{array}$ & +++ & +++ & ++ & ++ & - & ++ & - \\
\hline
\end{tabular}

Table 3: Phytochemical Screening of the Ethanolic Extract of Snake Plant (Sansevieria Trifasciata). +++ (Highly present); ++ (Moderately present); + (present) and - ( absent)

\section{Ten-fold dilution test}

\begin{tabular}{|c|c|c|c|c|c|}
\hline Tube \# microgram/ml & \#1 & $\# 2$ & \# 3 & $\# 4$ & \# 5 \\
\hline Volume of ASW (Diluent) & $10 \mathrm{~mL}$ & $9 \mathrm{~mL}$ & $9 \mathrm{~mL}$ & $9 \mathrm{~mL}$ & $9 \mathrm{~mL}$ \\
\hline Volume of Original Plant Extract $(10 \mathrm{mg} / \mathrm{mL})$ Serially Diluted & - & $1.0 \mathrm{~mL}$ & $1.0 \mathrm{~mL}$ & $1.0 \mathrm{~mL}$ & $1.0 \mathrm{~mL}$ \\
\hline Total volume in tubes \# 1 to \# 5 & $10 \mathrm{~mL}$ & $10 \mathrm{~mL}$ & $10 \mathrm{~mL}$ & $10 \mathrm{~mL}$ & $10 \mathrm{~mL}$ \\
\hline Dilution Series & 10-fold & 10-fold & 10-fold & 10-fold & 10-fold \\
\hline Dilution Level of Originated Extract & 1 & $1: 10$ & $1: 100$ & $1: 1,000$ & $1: 10,000$ \\
\hline Concentration of Plant extract in $\mathrm{mg} / \mathrm{mL}$ from tubes \# 1 to \# 5 & 10 & 1.0 & 0.1 & 0.01 & 0.001 \\
\hline Concentration of plant extract in ứg/mL or ppm from tube \# 1 to \# 5 & 10,000 & 1,000 & 100 & 10 & 1 \\
\hline
\end{tabular}

Table 4: Ten-fold dilution series of the Three dried powdered species of Sansevieria trifasciata in ASW of various concentrations ranging from 10, 000 ứg/mL to 1 ưg $/ \mathrm{mL}$.

The plant powder in tube \# $1(10 \mathrm{mg} / \mathrm{mL})$ was allowed to settle down for 1 hour. This should be produced a residue at the bottom and a clear supernatant liquid above it. After the plant powdered has settle to the bottom of tube \# 1, 1 mL of the supernatant was gently withdrawn using a $1 \mathrm{~mL}$ micropipettor and transferred to tube \# 2 . Tube \# 2 was corked and inverted 3 times to mix the content. Tube \# 2 was uncorked and return to its slot in the rack between \# 1 and \# 3 . Using again the micropipettor, $1 \mathrm{~mL}$ was removed from tube \#2 and transferred to tube \# 3 to tube \# 5 . This process performed is a 10 -fold serial dilution indicating that in each tube as one move from tube \# 1 to \# 5 , the concentration of the plant extract is being reduced by 10 times of the tube previous to it (Table 5).

\begin{tabular}{|c|c|c|c|c|c|c|c|}
\hline Well \# & $\begin{array}{l}\text { Conc. of } \\
\text { Snake Plant Leaves } \\
\text { Extract } \\
\mu \mathrm{g} / \mathrm{ml}\end{array}$ & $\begin{array}{l}\text { Log } 10 \\
\text { Conc. Of } \\
\text { Snake plant } \\
\text { Leaves } \\
\text { Extract }\end{array}$ & $\begin{array}{l}\text { Initial nos. of } \\
\text { shrimps }\end{array}$ & Shrimps surviving & Dead shrimps & $\begin{array}{l}\% \text { Mortality } \\
=\text { dead } \\
=\text { shrimps } \\
\text {-initial } \\
\text { shrimps } \times 100 \text { of }\end{array}$ & $\begin{array}{l}\% \quad \text { Mortality } \\
\text { (corrected for } \\
\text { control) }\end{array}$ \\
\hline 1 & 10,000 & 4 & 45 & 7 & 38 & 84 & $84-11=73$ \\
\hline 2 & 1,000 & 3 & 45 & 12 & 33 & 73 & $73-11=62$ \\
\hline 3 & 100 & 2 & 45 & 15 & 30 & 67 & $67-11=56$ \\
\hline 4 & 10 & 1 & 45 & 20 & 25 & 56 & $56-11=45$ \\
\hline 5 & 1 & 0 & 45 & 26 & 19 & 42 & $42-11=31$ \\
\hline Control & 0 (control) & ------- & 45 & 40 & 5 & 11 & -------- \\
\hline
\end{tabular}


Citation: Berame JS, Cuenca SME, Cabilin DRP, Manaban ML (2017) Preliminary Phytochemical Screening and Toxicity Test of Leaf and Root Parts of the Snake Plant (Sansevieria trifasciata). J Phylogenetics Evol Biol 5: 187. doi:10.4172/2329-9002.1000187

Page 5 of 7

Lethal Concentration @50 (LC50) = $44.49 \mu \mathrm{g} / \mathrm{ml}$ (Highly Toxic)

Table 5: Brine shrimp Bioassay for Snake Plant Leaves Extract Legend: 0-50 ppm (Highly Toxic); 51-100 ppm (Moderately Toxic); 101-200 ppm (Slightly Toxic); and 201 and above Not Toxic.

\section{Brine shrimp bioassay test}

Table 5 showed the bioassay using brine shrimp in the leaves extract of snake plant. It showed a high level of cytotoxicity level of 44.49 $\mu \mathrm{g} / \mathrm{ml}$. This means that leaves extract of snake plant is an effective medicinal plant and can be good medicinal plant especially as antibacterial agent due to the high toxicity level as shown in the Table 4 above. This only means that the root extract part is more effective herbal medicine compared with leaves extract since the number of surviving shrimps are more than the root extract's number of surviving shrimps as shown in Table 6 below.

\begin{tabular}{|c|c|c|c|c|c|c|c|}
\hline Well \# & $\begin{array}{l}\text { Conc. of } \\
\text { Snake Plant Roots } \\
\text { Extract } \\
\mu \mathrm{g} / \mathrm{ml}\end{array}$ & $\begin{array}{l}\text { Log } 10 \\
\text { Conc. of } \\
\text { Snake Plant } \\
\text { Roots } \\
\text { Extract }\end{array}$ & $\begin{array}{l}\text { Initial nos. of } \\
\text { shrimps }\end{array}$ & Shrimps surviving & Dead shrimps & $\begin{array}{l}\% \text { Mortality } \\
=\text { dead shrimps } \\
\div \text {-initial no. of } \\
\text { shrimps } \times 100\end{array}$ & $\begin{array}{lr}\% & \text { Mortality } \\
\text { (corrected } & \text { for } \\
\text { control) } & \end{array}$ \\
\hline 1 & 10,000 & 4 & 45 & 5 & 40 & 89 & $89-11=78$ \\
\hline 2 & 1,000 & 3 & 45 & 10 & 35 & 78 & $78-11=67$ \\
\hline 3 & 100 & 2 & 45 & 12 & 33 & 73 & $73-11=62$ \\
\hline 4 & 10 & 1 & 45 & 18 & 27 & 60 & $60-11=49$ \\
\hline 5 & 1 & 0 & 45 & 20 & 25 & 56 & $56-11=45$ \\
\hline Control & 0 (control) & ------ & 45 & 40 & 5 & 11 & ------- \\
\hline
\end{tabular}

Table 6: Brine shrimp Bioassay for Snake Plant Roots Extract Legend: 0-50 ppm (Highly Toxic); 51-100 ppm (Moderately Toxic); 101-200 ppm (Slightly Toxic); and 201 and above Not Toxic.

\section{Mortality rate of Nauplii Larvae}

This table showed that from the values of snake plant for its LC50 for roots of $35.22 \mu \mathrm{g} / \mathrm{ml}$ and LC50 of $44.49 \mu \mathrm{g} / \mathrm{ml}$ the brine shrimp bioassay, the root part is less effective when applied as an herbal medicine compared due to the number of less surviving shrimps and that it only proved that it can be less effective when its extracts are applied to these organisms and these events will be best observed or shown in Figure 1 below as the graph interpretation of comparing the Tables 4 and 5 respectively.

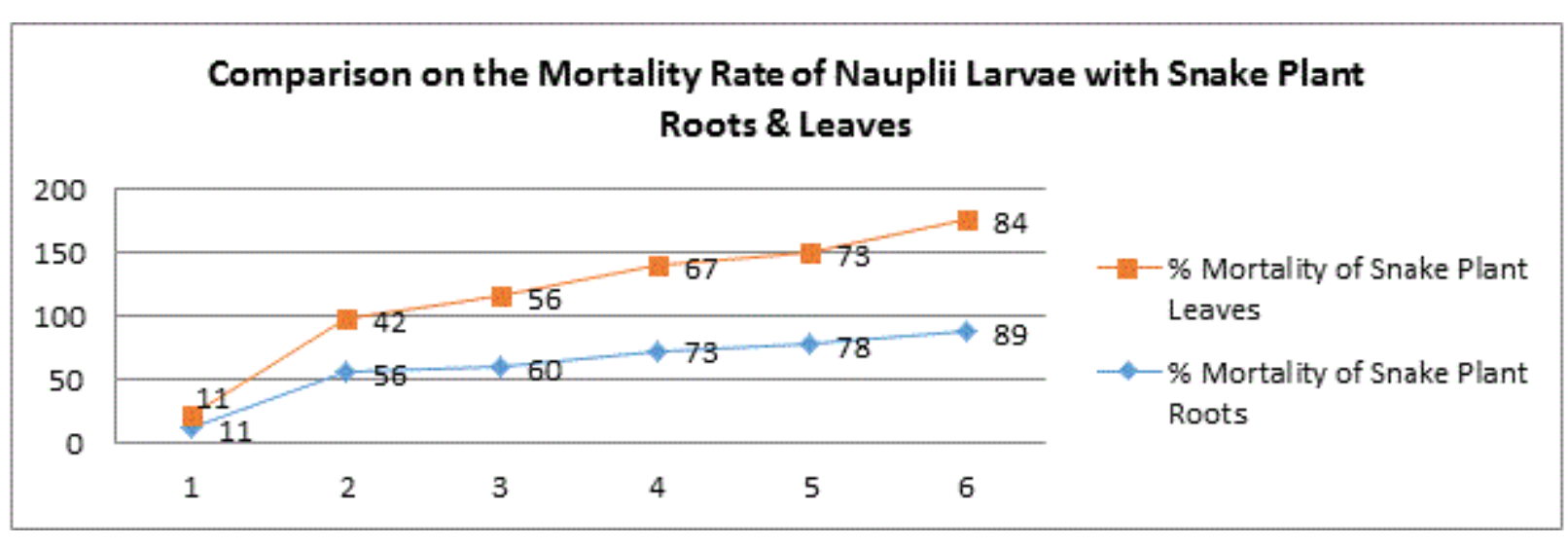

Figure 1: The Comparison between the Toxicity Levels of Snake Plant

This figure showed the comparative status of explaining the toxicity level of both extracts (plants and leaves) and will explain why leaves 
extract is more effective as shown in Table 4 and why the roots extract is less effective compared to the leaves extracts as shown in Table 5. This is the graph interpretation of the Tables 4 and 5 above.

\section{Discussion}

The screening of the plant material revealed the presence of the alkaloids, tannins, and antrhaquinones were summarized in Table 3. Ethanol extract yielded almost all above mentioned phytochemicals. Since our plant extract have revealed the presence of alkaloids, we can say alkaloids also have shown the antibacterial activity [14].

The evaluated antibacterial activity of alkaloid of Datura metel Linn leaves against Staphylococcus aureus, Pseudomonas aeruginosa, Proteus mirabis, Solmonella typhi, Bacillus subtilis and Klebsiella pneumonia but could not inhibit Escherichia coli [15]. Flavonoids are ubiquitous in photosynthesing cells and are commonly found in fruit, vegetables, nuts, seeds, stems, flowers, tea, wine, propolis and honey. For centuries, preparations containing these compounds as the principal physiologically active constituents have been used to treat human diseases [16].

Increasingly, this class of natural products is becoming the subject of anti-infective research, and many groups have isolated and identified the structures of flavonoids possessing antifungal, antiviral and antibacterial activity. The n-butanol purified saponin extract of sorghum bicolor were screened for anti-bacterial activity against three pathogenic microbes; Escherichia coli, Staphylococcus aureus and Candida albicans [17].

The extract inhibited the growth of the $S$. aureus. It was concluded that the saponins have inhibitory effect on gram-positive organism but not on gram negative organism and the fungi [18]. Saponin extract from Sider (Ziziphus spina_christi) were evaluated for his antibacterial activity against gram negative bacteria like E. coli, Proteus mirabilis and gram positive like Staphylococcus aureus and Streptococcus pneumoniae. The inhibitory effect in in vitro was defined to appear inhibition zone around the paper disc. The study revealed that $30 \%$ $(w / v)$ concentration most active against bacteria [19]. Compounds of pharmacological interest (tannins) were isolated from the plant species, Solanum trilobatum Linn and assayed against the bacteria, Staphylococcus aureus, Streptococcus pyrogens, Salmonella typhi, Pseudomonas aeruginosa, Proteus vulgaris and Escherichia coli using agar diffusion method.

Tannins exhibited antibacterial activities against all the tested microorganisms. Studies on the antibacterial activity of ethanol, methanol and aqueous extracts of dry flower and ethanol, methanol and acetone extracts of fresh flower of Cassia auriculata was conducted using agar disc diffusion method. The microorganisms used include Staphylococcus aureus, Enterococcus faecalis, Bacillus subtilis, Salmonella typhi, Salmonella paratyphi A, Escherichia coli, Proteus mirabilis, Pseudomonas aeruginosa, Klebsiella pneumoniae, Vibrio cholerae and Shigella dysentrae. The maximum activity was observed against all organisms except Pseudomonas aeruginosa and Klebsiella pneumonia [20].

The presence of important compounds which were separated by thin layer chromatography and the extract obtained by leaves and roots of the Sansevieria trifasciata showed potent antimicrobial activity. That the secondary metabolites in the plant extract was found out through its phytochemical analysis or screening process. Of which extract could be used for the treatment of various infections possessed as it possesses effective zone of inhibition. The toxicity of the extract when diluted with ethanol both the roots and leaves of the ST, its concentration showed that snake plant species can kill $50 \%$ of the Artemia salina nauplii at 24 hours, as a result from its test thru Brineshrimp Bioassay of its roots and leaves. As to the degree of lethality aspect of the study, the extractives were found to be directly proportional to the concentration of the extractives ranging from the lowest concentration $(35.22 \mu \mathrm{g} / \mathrm{ml})$ to the highest concentration $(44.49$ $\mu \mathrm{g} / \mathrm{ml})$. This concentration is an dependent increment in percent mortality of Brine Shrimp nauplii produced by the Snake plant and which indicates the presence of cytotoxic principles in these extractives hence, making it as an effective therapeutic remedy for gastric ulcer and will lend the credence to the folkloric use of these plants in treating microbial infection.

\section{Conflict of Interest Statement}

We declare that we have no conflict of interest.

\section{Acknowledgements}

The researcher wish to express his recognition to the Department of Biology and Chemistry Laboratory of Caraga State University for allowing the researcher to use the laboratory apparatus.

\section{References}

1. Cushnie J (2008) How to Prune: Techniques and Tips for Every Plant and Season. Kyle Cathie; illustrated edition, USA.

2. Bañez S (1995) Phytochemical Screening and Pharmacological Testing of Sanggumay Orchid (Dendrobium superbum Reichb). UNP Res J.

3. Dhanalakshmi D, Kumar S, Prasad MS, Koli V, Kumar BP, et al. (2011) Analysis of Preliminary phytochemicals of leaf extracts of Cleome gynandra. Eur J Exp Bio 1: 103-105.

4. Kredy L (2010) Phacoemulsification-induced injury in corneal endothelial cells mediated by apoptosis: In vitro model. Elsevier Inc 34 : 2146-2152.

5. Lacaille-Dubois MA (2007) Bioactive saponins from plants: recent development in Yaniv Z and Bacherach U eds. Handbook of Medicinal plants: India, Harworth Press.

6. Lawinsohn E, Tadmor Y (2007) Biotechnology in medicinal crop improvement in Yaniv Z and U Bacherach eds. Handbook of medicinal plants: India, Harworth press.

7. Maiscott M (2000) Curing everyday ailments the natural way. New York: The Reader's Digest n Association, Inc.

8. Doss D (2009) Structural Insight into the Heme-based Redox Sensing from Mycobacterium tuberculosis. ASBMB J Lipid Res.

9. Anyasor C, Austria S (2010) Comparative study of phytochemical screening, antioxidant and antimicrobial capacities of fresh and dry leaves crude plant extracts of Datura metel: L King Saud University. Elsevier.

10. Chandrappa GT, Nagaraju G, Tharamani CN, Livage J (2007) Hydrothermal synthesis of amorphous MoS2nanofiber bundles via acidification of ammonium heptamolybdate tetrahydrate. Nanoscale Res Lett 2: 461-468.

11. Guevarra L (2004) Clinical Data Mining for Physician Decision Making and Investigating Health. Idea Group Inc, Manila, Philippines.

12. Bose A, Mondal S, Gupta JK, Ghosh T, Si S, et al. (2007) A Study on Antimicrobial Activity of Cleome rutidosperma DC. J Nat Remedies 7: 132-134.

13. Meyer R, McLaghin Al (2004) Fe3O4@NiFexOy Nanoparticles with Enhanced Electrocatalytic Properties for Oxygen Evolution in Carbonate Electrolyte. ACS Appl Mater Interfaces 8: 29461-29469. 
Citation: Berame JS, Cuenca SME, Cabilin DRP, Manaban ML (2017) Preliminary Phytochemical Screening and Toxicity Test of Leaf and Root Parts of the Snake Plant (Sansevieria trifasciata). J Phylogenetics Evol Biol 5: 187. doi:10.4172/2329-9002.1000187

Page 7 of 7

14. Nair P (2008) Advancing Medicine through Nanotechnology and Nanomechanics Applications. IGI Global.

15. Prajapati ND (2007) A Handbook of Medicinal Plants: A complete source Book-India, Agrobios publishers.

16. Essiett UA, Ukpong UJ (2009) Comparative Phytochemical, Nutrient and Anti-Nutrient of Stems of Ipomoea Involucrata Beauv, Ipomoea. Triloba L. and Ipomoea Batatas Lam. American J Food Nutr 2: 71-76.

17. Pugulayan R, Samonte IE, Mayer WE (2004) Molecular phylogeny of Philippine freshwater sardines based on mitochondrial DNA analysis. J Hered 91: 247-253.
18. Soetan K, Otesile AT, Adedapo A (2006) Assessment of the Anthelmintic Efficacy of an Aqueous Crude Extract of Vernonia amygdalina. J Pharm Biol 45: 564-568.

19. Wadher B (2012) Treatment of superficial pseudomonal infections with citric acid: an effective and economical approach. Elsevier Inc.

20. Maneemegalai S, Meenatchi P, Purushothamman A (2017) Antioxidant, antiglycation and insulinotrophic properties of Coccinia grandis (L.) in vitro: Possible role in prevention of diabetic complications. J Tradit Complement Med 7: 54-64. 